\title{
Erratum to: An IGRT margin concept for pelvic lymph nodes in high-risk prostate cancer
}

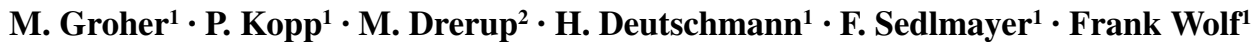

Published online: 1 September 2017

(C) Springer-Verlag GmbH Deutschland 2017

\section{Erratum to:}

Strahlenther Onkol 2017

https://doi.org/10.1007/s00066-017-1182-1

The authors apologize for a typing error in the German title. The correct German title should be:

Ein IGRT-Sicherheitsrand-Konzept für den pelvinen Lymphabfluss bei Hochrisiko-Prostatakarzinomen

The online version of the original article can be found under https://doi.org/10.1007/s00066-017-1182-1.

Dr. Frank Wolf, MD-PhD

f.wolf@salk.at

1 Department of Radiation Oncology, St. Johanns-Spital, Paracelsus Medical University of Salzburg, Müllner Hauptstraße 48, 5020 Salzburg, Austria

2 Department of Urology, St. Johanns-Spital, Paracelsus Medical University of Salzburg, Müllner Hauptstraße 48, 5020 Salzburg, Austria 